\title{
O jornalismo de Sylvio Floreal em A Coragem de Amar: texto, contexto e pretextos
}

Resumo:

O momento referendado como Primeira República (1889-1930) pela periodização política brasileira marcou, como se sabe, de modo transversal o processo de profissionalização dos escritores, assim como da esfera literária em geral. O jornalismo, por sua vez, ao abrir caminho enquanto instância econômica, fazendo da notícia, muitas vezes incorporada pela literatura, um objeto de consumo, torna-se, não sem contradições, uma das mais importantes ferramentas para o exercício autonômico da escrita criativa. É a partir desse contexto que abordamos a trajetória do escritor santista Sylvio Floreal, pseudônimo de Domingos Alexandre (18931928), a quem a luta para ocupar um lugar nas letras em uma metrópole que se industrializa a toque de caixa, em meio a convulsões sociais de diversas ordens, como é o caso da cidade de São Paulo, torna-se decisiva, ao ponto de ganhar espaço e tratamento em sua produção. De igual maneira, sob a continuidade entre jornalismo, capitalismo e literatura, o romance A Coragem de Amar, publicado em 1924 e reeditado em 1925, será analisado em diálogo com os discursos sobre a modernidade próprios da época, os quais se manifestaram de maneira complexa e determinante para a nossa história cultural, ecoando até os dias atuais.

Palavras-chave:

Jornalismo, Literatura em São Paulo, Primeira República (1889-1930), Sylvio Floreal

\section{Abstract:}

The moment referred to as the First Republic (1889-1930) by the brazilian political periodization marked, as is known, in a transversal way the professionalization process of the writers, as well as the literary sphere in general. Journalism, in turn, when making way as an economic instance, making news, often incorporated by literature, an object of consumption, becomes, not without contradictions, one of the most important tools for the autonomous exercise of creative writing. It is from this context that we approach the trajectory of the writer, from Santos, Sylvio Floreal, pseudonym of Domingos Alexandre (1893-1928), to whom the struggle to occupy a place in letters in a metropolis that industrializes quickly, amid convulsions of different orders, as is seen in the city of São Paulo, becomes decisive, to the point of gaining space and treatment in its production. In addition, under the continuity between journalism, capitalism and literature, the novel $A$ Coragem de Amar, published in 1924 and reedited in 1925, will be examined in dialogue with the speeches 
about modernity of the time, which were manifested in a complex way and determinant for our cultural history, echoing to the present day.

Keywords:

Journalism, São Paulo literature, First Republic (1889-1930), Sylvio Floreal

Localizada E a situação permanece a mesma: de um lado a imprensa assalariada que tem ânsias de vender o país a retalho; do outro lado o povo cansado de ser ludibriado, explorado, traficado, cruza fakirianamente os braços e deixa tudo ocorrer à revelia, frio, impassível, inerme, pusilânime, sem o mínimo vislumbre de revolta e de indignação.

Sylvio Floreal - "Um grito no deserto", Atitudes 1922.

\section{Considerações preliminares}

A figura de Sylvio Floreal, pseudônimo de Domingos Alexandre (1893-1928), foge aos desígnios que constituem historicamente a formação do escritor brasileiro referendado pela posteridade, passando ao largo de nossa seletiva tradição literária. Foi pedreiro e intelectual autodidata, formado nas bibliotecas da Escola Noturna, mantida pela Federação Operária de Santos, sua cidade natal, bem como uma figura arredia, desprendida das vaidades intelectuais do período que ganharam volume com os movimentos de institucionalização do conhecimento a partir da formação das academias de letras, crescimento de agremiações e ocupação em cargos políticos por literatos; o que não significa dizer, por outro lado, que, ao negar determinadas demandas da sociabilidade literária da época, não tenha aderido a outras como, por exemplo, o jornalismo de grande circulação. Aliás, o jornalismo, à época, e para ele não foi diferente, era ao mesmo tempo ponto de consenso e dissenso frente à arte mais acadêmica e, igualmente, sintoma de subserviência e subversão do intelectual, que podia fazer da imprensa um palanque pessoal ou militante, de cunho coletivo, dialeticamente. Não seria descuido dizer que Floreal foi por excelência jornalista, apesar de sua inicial resistência à profissão, imperativa aos escritores.

Seu primeiro livro, Atitudes, publicado em 1922, é composto por uma coletânea de escritos jornalísticos dispersos e outros textos; Ronda da Meia Noite: vícios, misérias e esplendores da cidade de São Paulo, 1925, ${ }^{1}$ reportagens sobre a cidade de São Paulo e suas personagens marginalizadas já estava no prelo em 1922; A coragem de amar, 1924, reeditado em 1925, guarda muitas características observadas nas reportagens, especialmente no que diz respeito ao impulso de desnudamento social; e, por fim, o Brasil Trágico: Impressões, visões e mistérios do Mato-Grosso, 1928, espécie de diário de viagem que mantém intacta a argúcia da observação aperfeiçoada no decorrer de toda a sua produção e vivência jornalística enquanto repórter. ${ }^{2}$ 
Um importante adendo ao debate que rodeia a complexa relação entre literatura e jornalismo, que condiciona as análises aqui sugeridas, está notavelmente localizado em parte fundamental do trabalho de Ángel Rama. Ao circunscrever a condição das letras na América Latina - com o raro cuidado de percorrer as distinções não só entre o Brasil e os demais países, dada as particularidades históricas estruturantes que se destacam das evidentes similaridades, mas também entre os países que carregam maiores denominadores comuns do ponto de vista social e cultural, como a língua, por exemplo, sem cair nas banalidades que podem fazer surgir uma simples análise por aproximação territorial - trata de privilegiar três tópicos comuns ao cenário literário emergente da época aqui estudada, os quais servirão de base para entendermos o lugar de Sylvio Floreal e as contradições intrínsecas ao seu percurso: "incorporação de doutrinas sociais", "autodidatismo" e "profissionalismo" (Rama 2015: 113-139). Definitivamente, Floreal passa por tais processos de forma tão evidente e intensa que podemos dizer que a partir deles compreendemos muitos dos impasses do escritor, seja em termos de suas motivações literárias, passando pelas resignações e recusas ao campo literário vigente, assim como, por conseguinte, suas realizações formais que, em resumo, sempre terminam por acumular as esferas literárias e jornalísticas com alguma organicidade.

A "incorporação de doutrinas sociais" se dá para o escritor de modo conjugado com seu "autodidatismo". Isso porque a formação que a Escola Noturna, que mencionamos acima, previa para seus membros na cidade de Santos, a Moscou brasileira, ${ }^{3}$ uma formação intelectual e política, de viés radical, originada pela atuação anarquista, mais especificamente anarco-sindicalista, a qual prevalecia em São Paulo no momento, a partir de uma configuração de atuação social formada em larga escala por revolucionários, em sua maioria imigrantes europeus de origens distintas que aportavam na cidade, diferentemente do Rio de Janeiro que, sob pena de generalização, mantinha um quadro de atuação mais reformista, constituído por trabalhadores brasileiros (Sarti 1981: 85). Desse modo, a partir da formação literária e política de Floreal nas bibliotecas da Escola Noturna, onde teve acesso a obras de escritores e jornais de várias partes do mundo, iniciou sua produção por meio da redação de manifestos de ocasião em jornais operários. Posteriormente, colaborou também com veículos de maior circulação como as revistas A Cigarra, Panoplia, O queixoso, A vespa, trabalhando também na direção de A Flecha, e, dentre os jornais, $O$ Estado de S. Paulo, Correio Paulistano e Gazeta.

Mas a passagem de seu "autodidatismo", pois nunca frequentou qualquer instituição de ensino formal em qualquer que seja o nível de escolarização, para o "profissionalismo", sobretudo por meio da adequação às redações de jornal, não foi nada simples e nem se concretizou definitivamente. Antes de assumir o papel de jornalista, foi funcionário pouco dedicado dos Correios e, antes ainda de trabalhar na revisão de jornais, por insistência dos amigos, função que já não gozava de prestígio algum para quem almejava a carreira de escritor, chegou a exercer a função de vendedor de assinaturas, ${ }^{5}$ percorrendo todo o caminho do jornalismo, do mais rejeitado ao mais vislumbrado, este vinculado, evidentemente, à figura de escritor profissional. O depoimento do amigo e conterrâneo santista Ribeiro Couto, participante da Semana de Arte de 1922, publicado na Illustração Brasileira em 1928, poucos meses depois da morte do 
escritor, conta com muitas passagens sobre a difícil vida que levava o escritor e aponta a sua inicial rejeição absoluta pelo jornalismo, e por cargos em repartições, evidenciando o quanto tal postura o diferenciava dos jovens colegas e futuros escritores que conviviam no pequeno círculo intelectual paulista:

Nossa queda era toda para o jornal, naquele grupo. Ele desprezava o jornal - miserável espécie de literatura improvisada [...]. Paulo Gonçalves, Albertino Moreira e eu embarafustamos, enfim, pelas revisões dos jornais. Ganhávamos. E, por isso, queríamos meter à força o autor da "Tortura da gloria" ${ }^{6}[. .$.$] naquele caminho de cavar o pão [...]. Tudo para ele que não fosse o círculo das$ suas admirações literárias [...] era burguês. (Couto 1928)

"Último boêmio da Paulicéia", como quis o cartunista Belmonte em publicação na revista carioca Dom Casmurro em 1942, foi apartado inclusive pelos amigos literatos que não mais se identificavam com a figura do escritor adepto à vagabundagem das noites e inconsistência em sua produção e visão de mundo rebelde, cujo talento, segundo Ribeiro Couto, - um dos poucos a manter qualquer laço afetivo com o escritor, ainda que somente companheiro de madrugada ocasional, impossível de apresentá-lo à família - foi "sacrificado pela indisciplina, pela falta de instrução sequer primária e pela ilusão de um autodidatismo precário" (ibidem). O depoimento ilustra bem o conflito em torno da nova atmosfera intelectual que cercava o escritor brasileiro, a quem a vida desregrada e idealista conflitava com as novas possibilidades profissionais e pragmáticas de um recente contexto que requeria produção e desempenho, além de estratégias de condicionamento institucional e fortalecimento de uma imagem pública imaculada ou, ainda, domesticada:

Nós a andar pelas calçadas, a procurar trabalho, a andar limpos, a comprar livros que queríamos ler, a sentir a precisão honrada de comer com regularidade; ele a deixar o cabelo crescido, a procurar convícios torvos de botequins, a aparecer com livros que suspeitávamos furtados, a renegar de jornais, de repartições, do comércio, da indústria, das atividades nacionais em geral, de tudo que exige os fundilhos atados de uma mesa durante cinco horas e um pouco de asseio nas unhas [...] a esconder-se de todo o trabalho metódico, porque o trabalho (salvo a composição de suas páginas) era burguês! (ibidem)

Com tal, a obra de Sylvio Floreal é povoada por seu processo truncado de autonomização, que frequentemente permuta sua atuação essencialmente ácrata com as instâncias de legitimação em nome de uma permanência possível para alguém que não detinha capital intelectual legitimado pela Faculdade de Direito do Largo São Francisco, caminho prévio obrigatório para os aspirantes a escritor na cidade, e nem econômico, obstaculizando a publicação de livros com recursos próprios, como também era de costume entre os literatos de modo geral. $\mathrm{O}$ autor paulista foi membro de um grupo de esquerda formado por escritores chamado Zumbi, tendo à frente o também escritor santista Afonso Schmidt, com base no grupo Clarté, capitaneado 
por Henri Barbusse, na França.7 O grupo foi desmembrado "devido, sobretudo, às condições policiais da época" em um momento de "politização literária de objetivos socialistas" (Brito 1997: 147). O resultado é um arranjo estratégico que convém suas atribuições políticas e ideológicas, permanentes em sua obra, em conjunto com demandas de um público leitor de uma produção de consumo imediato, formado pelos jornais, único meio possível, talvez, para um escritor com uma imagem como a sua ter qualquer presença em São Paulo, quer pela atuação jornalística particularmente quer pela incorporação de características desta atividade na literatura. É a partir desse contexto complexo, e não raro contraditório, que devemos conduzir a leitura de sua obra como um todo, mas, especialmente, A Coragem de Amar, que carrega, segundo cremos, tais paradoxos de modo bastante significativo, justamente por ser seu único romance propriamente dito, para a compreensão dos elementos literários e sociais em cena em um momento que entendemos crucial de nossa história cultural.

\section{Entre a tensão do jornalismo comercial e militante, A Coragem de amar}

O livro representa a atividade jornalística desde sua concepção e contexto à sua costura narrativa, estrutural. O primeiro ponto que emerge do romance, nessa direção, é Marcos Valerio, personagem advinda da pequena burguesia que por acaso tropeça na profissão de jornalista no periódico fictício Jornal da Manhã, encabeçado pelo ambicioso Fernando Mancini. Exerce o papel de redator da seção "Crônica Social", a qual acompanha a vida das figuras de interesse público da cidade, isto é, que exercem alguma proeminência, forjada, via de regra, pela própria imprensa. Ao reencontrar o amigo de infância Bruno Torelli no primeiro quarto do romance, que em determinado momento da vida optou por morar em Mato Grosso, passando uma temporada em São Paulo com o intuito de resolver assuntos pessoais e visitar o pai, Marcos expõe sua posição da seguinte forma diante da grata reação do amigo quando soube de sua condição de homem de imprensa: "Confesso-te que a minha entrada para a imprensa foi uma brincadeira de mau gosto do acaso, uma desemxabida pilhéria do destino. A minha entrada para o "Jornal da Manhã" foi combinada numa esquina, numa tarde de chuva. A esquina!" (Floreal 1925: 28).

Há uma dimensão de rebaixamento na fala de Marcos em relação à atividade jornalística, esclarecendo ao amigo, por meio de sua experiência, alguém de dentro da imprensa, que não só o acaso promoveu a sua entrada no jornal, o que desmistifica uma possível glamorização intelectual nos meios de comunicação impressa, mas também remonta a certa simetria decadente entre a profissão e as práticas sociais que podem estar em associação à esquina, como prostituição ou atividades tidas por licenciosas de modo geral, muito frequentes como tema tanto no fazer jornalístico de Floreal quanto no próprio romance, fator que dá indícios desta interpretação para o leitor que acompanha seu percurso nos periódicos ou mantém fresco na memória o clima anunciado desde o início da narrativa, arrolado por uma incursão ao submundo urbano, como, por exemplo, o breve trecho que aparece anteriormente, como uma espécie de abertura do diálogo acima: 
Cadernos de Literatura Comparada

O jornalismo de Sylvio Floreal em A Coragem de Amar: texto, contexto e pretextos

Seis horas da tarde.

Negligentemente, a noite anunciava sua chegada.

Gritos, pregões, vozes perdidas no ar brando, claudicavam na meia tinta o crepúsculo que vinha caindo.

Mulheres da vida airada, de cabelos violentamente loiros, comprometedores, de mistura com mulheres que disfarçavam inteligentemente o seu modo de vida, sentadas no saguão da "Rotisserie", acariciavam o pelo sensual dos seus pomerianos lanzudos, de nariz gracioso e viciado, ou conversavam discretamente com indivíduos que fatalmente lhes abrem a bolsa.

Bruno, lembrando suas antigas tardes de aperitivos, levou Marcos pelo braço ao interior da "Rotisserie Sportsman". (idem: 25-26)

Assim como Bruno, Marcos conhecia Mancini desde sua infância, pois moravam no mesmo local, onde seus pais mantinham um pequeno comércio na rua Catumbi, região do bairro Belenzinho. Desempregado depois da morte do pai, Mancini, diretor-secretário do periódico, oferece para Marcos uma posição no jornal. Após justificar tal contexto, atenuando, mais uma vez, a admiração do amigo, Marcos relativiza o trabalho, "Aquilo não é um bicho de sete cabeças. Com um pouco de boa vontade, e sabendo escrever, consegue-se fazer o que todos fazem" (idem: 29). Contudo, Bruno, desconfiado do descrédito da profissão do amigo responde complacente: "- Entrar para um jornal é fácil, não há dúvida, disse Bruno com um sorriso levemente irônico." (ibidem). Em seguida, Bruno pergunta sobre o papel exercido por Fernando Mancini no jornal, seu contratante. Marcos responde com o mesmo temperamento, reconduzindo a visão do amigo acerca de Mancini, a quem o cargo superior de diretor-secretário não o classifica, segundo a percepção da personagem, como alguém dotado de grandes capacidades ou inclinações: "- Te admiras? Pois não é necessário ter talento nem ser jornalista para se chegar a tal. Basta simplesmente um pouco de senso prático, alguma audácia e um grande desejo de ser alguma coisa, e nada mais." (idem: 30).

Importante perceber que, através da perspectiva das personagens em diálogo, está posta a inflexão histórica que distingue a noção do homem de imprensa ligado à intelectualidade em nome de forças políticas e aptidões superiores, que caracterizou o jornalismo que precedeu a República, não sem suas formas próprias de hierarquização e manutenção de poder, da que se praticava intensamente por sujeitos ligados a, e em nome de, estruturas econômicas, de quem se espera atribuições menos louváveis e sublimes, visto que "senso prático, alguma audácia e um grande desejo de ser alguma coisa" suplanta de modo indeterminado qualidades tais como talento, vocação e preparo. É de se notar também que a visão idealizada da personagem Bruno advém da sua condição de classe que, por não pertencer às esferas de poder influente, pouco sabe sobre como estas estão estruturadas e forjadas pela nova configuração da imprensa, restando aos seu senso comum a ideia comprometida da prática jornalística e da palavra impressa, lugar cujo alcance passa por uma vaga noção de brilhantismo excepcional, sobretudo avistando alguém que como ele, isto é Marcos, amigo de infância, tem sua origem na pequena burguesia. Mais adiante no romance, o pai de Bruno também compõe a convicção 
de que o homem da imprensa executa uma tarefa incomum porque especial, olhando Marcos com notabilidade em uma curta passagem do texto, na qual se dá seu reencontro com o velho Giacomo: "- Trabalha de noite? - Sim papai. É redator do "Jornal da Manhã". O velho completou a admiração, medindo-o de alto a baixo." (idem: 120). Podemos situar historicamente o conflito presente no imaginário social da época da seguinte maneira:

O jornalista, figura antes associada a uma elite do porte de um Hipólito da Costa, ou mesmo de grandes políticos do Império, agora aparece como manipulador, arrivista e corrompido. E ligado a um tipo de escrita que vinha sob a bandeira da informação, mas frequentemente desmascarado como enganação (Guimarães 2009: 238)

Imprensa e interesses econômicos da elite são atribuições que se delineiam numa espécie de continuidade inerente e não mais como setores apartados na sociedade, e assim é transfigurado no romance. A narrativa evidencia acidamente o quanto a interdependência entre as esferas reforça uma maior concentração de poder por parte dos que historicamente traçam uma trajetória de conservação e centralização de privilégios sociais adquiridos no decorrer da história. Mancini é a personagem a partir da qual se compreende tal mecanismo, proveniente de uma dinâmica social em aprimoramento vivaz no período, o que faz emergir a atualidade do romance, em sua tentativa de constatação crítica, uma proposta de desnudamento social:

No automóvel Club, no meio dos ricos e novos-ricos, ele completaria a carreira começada no jornal. Chegaria até onde quisesse, porque o "Jornal da Manhã", fundado com capitais de lavradores abastados, estava totalmente entregue à sua direção. Não tinha talento, nem cultura, predicados dispensáveis para um diretor de jornal (Floreal 1925: 88)

Com maior ou menor intensidade, essa interlocução é indicada de maneira bastante significativa no trânsito do enredo. Assim, do outro lado do espectro social, a ingerência dos mais abastados, ou dos que se engolem para sê-lo, resume com outras lentes o papel da imprensa, de modo que é vista como espaço por meio do qual se pode subjugar o que entender conveniente em nome das vaidades e posições sociais em disputa acirrada. A figura da personagem Oswaldo é central para tal entendimento, uma vez que, sendo ele um bacharel, filho da classe política e exímio conhecedor das artimanhas do submundo e da elite, torna-se, após um grande jogo de máscaras e estratégia interessada, o marido de Lydia, filha da elite econômica, totalmente submissa à vontade da família, com sua identidade extensivamente apagada. Com os olhos no dinheiro da família, o caça-dotes ${ }^{8}$ Oswaldo, com a ajuda cuidadosa do tio, também peça influente da política oficial, vai alcançando seus objetivos com as mais variadas formas de ganância e insolências, a todo momento pontuadas pelo narrador. Fato é que ocupa não só a posição de marido de Lydia, por quem não nutria sentimento afetivo algum, mas também se torna referência prestigiosa dentro do seio familiar da esposa, colocando em prática seus planos em nome de maior preponderância e distinção social, sempre com vistas ao acúmulo 
econômico. Marcos, que em uma de suas atribuições de redator de crônica social, é designado pera cobrir a festa de aniversário de Oswaldo, conhece Lydia, apaixonando-se por ela e sendo correspondido. Passam a viver a paixão secretamente e assim que descobertos por Oswaldo, exclusivamente preocupado com a sua fonte financeira, braveja:

- Um amante! E logo quem! Um desclassificado, um anônimo, um João Ninguém, um reles fazedor de notícias de jornal, que provavelmente a quer explorar com a sua babugem de faminto enamorado.

Ele proferia isto dando um falsete às palavras, a fim de infundir um certo asco no que ia dizendo, como para patentear a distância que ia entre ele, filho de senador da República, bacharel, e Marcos, que não era filho de senador, nem possuía nenhuma carta. (idem: 106)

Se para ele Marcos não passava de um "João Ninguém" ou "reles fazedor de notícias de jornal", fator que contradiz a visão das personagens Bruno e seu pai, Giacomo, que viam com muita estima a figura do redator, sempre orgulhosos do amigo. Mancini, ao contrário, por exercer maior capacidade de intervenção no mesmo jornal, ainda que carente de qualidades técnicas próprias para ocupar tal função, aparece para Oswaldo como um aliado, alguém a ser meticulosamente incorporado pelo seu círculo restrito de influências superficialmente planejado:

Oswaldo, por essa atração que infunde e esse respeito que espalha em torno de si um homem de imprensa, procurava-o sempre, mesureiro, obsequiador, fazendo-lhe prodígios de amabilidades. Aproximou-o também do sogro e do cunhado. Este, ele achava que, se fosse um pouco mais esperto, poderia também dedicar-se à carreira jornalística. A esperteza era, a seu ver, a única qualidade necessária para o jornalista. (idem: 88)

E dessa afinidade entre os setores cobiçosos da sociedade e o crescimento do jornalismo industrial, também um degrau rumo à diferenciação social, da qual origina um elo cada vez mais coeso, indissociável mesmo, no âmago dos processos de modernização e urbanização, consolidando-se como notório o fato de que "a imprensa se torna manipulável à medida que se comercializa" (Habermas 2014: 402), emerge pelo menos dois efeitos trágicos no bojo do romance, quais sejam, a pauperização social aliada à manipulação do imaginário de camadas populares da sociedade e a árdua perseguição do casal Marcos e Lydia em prol da proteção da fortuna de Oswaldo; elementos estes que, em grande medida, não fazem parte de fenômenos exatamente distintos.

O primeiro termo ganha estatuto didático no enredo: Fernando Mancini é condecorado e financiado pelo dono das Indústrias Unidas e Ramificadas, nome fictício bastante genérico como forma de fazer apontamento crítico a uma prática difundida, pelo então Conde Fausto Mariolloni. Diante de uma reivindicação grevista, o jornal toma partido dos interesses do Conde como estratégia de angariamento financeiro e prestígio social, uma vez que após posicionar-se 
a favor das Indústrias Unidas e Ramificadas, incitando a atuação policial de modo a reprimir duramente os trabalhadores, recebe sua contrapartida em dinheiro e em forma de título, dada à transformação do diretor do jornal Fernando Mancini em Cavagliere Ufficiale dela Corona d'Italia:

Não porque ele fosse descendente de italiano, nem tão pouco pelos seus altos méritos, não! A causa devia ser outra, bem diferente.

Fora porque, numa greve do pessoal da Industrias Unidas e Ramificadas do Conde Fausto Mariolloni, o "Jornal da Manhã", com as finanças então seriamente abaladas, sob a direção exclusiva do seu redator-secretário, que vergara o caráter, afim de ganhar dinheiro, até tocar a raia de todas as transigências possíveis, achou que era ótima política defender os capitais formidolosos do Conde, fazendo carga cerrada sobre os grevistas que eram na maioria italianos e que imploravam simplesmente um aumento de salários.

E o "Jornal da Manhã", defendeu o industrial desbragadamente, abertamente, com olho grosso no seu dinheiro.

A polícia completando a obra do jornal, prendeu os famintos que reclamavam uns tostões a mais, famintos esses que ela chamava de "anarquistas", coisa, aliás, que os pobres ignorantes trabalhadores não sabiam bem o que era.

E quando a greve acabou, os operários, com a tuberculose latente a formar ninho de cupim nos pulmões, agravada pelos rigores das enxovias, todos, aos magotes, cabisbaixos, humilhados, maltratados pela polícia, injuriados pelo jornal e reduzidos ao estado de miserabilidade pela fome e pelas doenças, voltaram ao trabalho. Dois dias depois da greve terminada, o "Jornal da Manhã" num alto torneio de bajulação, num formidável surto de bem acabado rapapé, estampava na sua primeira página, entre molduras floridas, o retrato do Conde Fausto Mariolloni, com elogios que o qualificavam de "benemérito", protetor disto e daquilo, num rasgado bonito de engrossamento, que, segundo Mancini, ainda pareciam poucos para um homem como o Conde, o qual, merecendo muito mais, devia, no mínimo, ser conde duas vezes.

O Conde, defendido e ainda elogiado, apesar de já estar acostumado a essas coisas, enterneceu-se, comoveu-se sinceramente e canalizou alguns contos de réis da burra das Indústrias Unidas e Ramificadas, para o pequeno cofre do "Jornal da Manhã". Fez ainda muito mais: porquanto, vendo que isso seria apenas uma prova de atenção material, e com um simples pedido seu à Itália, arranjou para o diretor do "Jornal" aquele título honorífico de Cavalheiro. (Floreal 1925: 132-134)

A titulação de Fernando Mancini garante ao seu perfil um incontornável capital social que, acompanhado de um préstimo financeiro, inaugura às claras a venda do jornal, transformando-o em mais que instrumento sólido de defesa da burguesia em ascensão, da qual ele mesmo é partícipe, no seu meio de propaganda ideológica tutelada. O episódio é importante na narrativa por fornecer um indício do que será visto mais especificamente no interior do núcleo reduzido do enredo, ou seja, na vida amorosa de Marcos e Lydia, assim como pontua a continuidade entre as funções coadunadas entre os títulos honoríficos, típicos da Monarquia e a soma em 
dinheiro, próprias da vigente fase da história social republicana. Aliás, é recurso recorrente da obra, condicionado a uma postura pedagógica, que podemos localizar o texto em uma moldura militante, um movimento pendular que confere dentro da prática social geral, com muitas digressões, comentários e veia ensaística, típicas de um cronista-narrador, a sua circunstância detida, em resumo recolhida pelo microcosmo das ações das personagens em conflito mais localizado.

Exemplo dessa solução narrativa é visto quando a intervenção de Oswaldo, acompanhado pelo pai de Lydia, abduzido pela grande eloquência gananciosa daquele, e Polycarpo, coronel que enriqueceu com a alta do café (frequentemente perfilado no romance por sua adesão ao meretrício urbano da elite, o qual também passava por um processo de otimização em conformidade com o crescimento da cidade), provoca a demissão de Marcos do jornal junto a Fernando Mancini. A demissão passa por cima de qualquer resquício de amizade que Marcos mantinha com Fernando, sendo aclaradas no romance as verdadeiras motivações deste, a quem o dinheiro e o jogo de influências sempre falavam mais alto. Aqui percebemos também o resultado daquela estratégia de Oswaldo ao aproximar-se do diretor do jornal nos circuitos mantido pela alta burguesia, da qual o Automóvel Club é síntese no enredo junto com as casas de prostituição, onde também eram feitos os acordos de setores da elite. ${ }^{9}$ Assim, a demissão de Marcos é plantada no jornal, seguida de sua posterior prisão, que conta com a intervenção de uma das prostitutas próximas a Polycarpo, Flor do Mal, apelido dado pela fama que ganhou nos jornais..$^{10}$ Subornada, endossa contra Marcos um crime de lenocínio, com a conivência de um delegado também induzido, prontamente divulgado pelos jornais, que, por sua vez, mantinham interesses nesse tipo de acontecimento, ou melhor, de narrativa, nem sempre factual, subordinada a atração de leitores, como mostrado no episódio do romance: "[...] todos os jornais publicaram o retrato de Marcos, ao mesmo tempo que o apontavam à promotoria pública por crime de lenocínio. $\mathrm{E}$ quem mais fazia carga fechada sobre Marcos era justamente o "Jornal da Manhã " (idem: 184). Importante perceber a sincronia entres as esferas que atuaram paradoxalmente "ao mesmo tempo", aclarando o arranjo em torno das evidências forjadas sobre Marcos em nome da preservação da fortuna apossada por Oswaldo. O Jornal da Manhã, por sua vez, ao intensificar a notícia, destaca-se do coro feito por outros periódicos, - que atuavam de modo a promover uma narrativa que envolvesse os leitores, sem compromisso com os fatos - porque mantinha grandes interesses particulares que poderiam render maior presença do jornal no âmbito econômico, atestando a indiferença diante do compromisso com a informação, o que não interessava à imprensa de modo geral, em favorecimento da relação com Oswaldo e outros figurões da alta burguesia.

Como dois polos aparentemente segmentados da narrativa, o romance de Marcos e Lydia acontece com grandes rasgos de idealismo aventureiro e tentativa de superação das convenções sociais, que acabam por persegui-los, minando o empenho amoroso, constituído com muita pureza e devoção, em uma progressão narrativa dotada de altos e baixos típicos dos romances folhetinescos. De um lado, temos então a atmosfera social construída e criticada pela escrita dura e cáustica de um narrador-observador impenitente e, de outro, as ações e falas das duas 
personagens postas em cena por meio de diálogos e trocas de cartas longas e apaixonadamente morosas, expondo o drama de viver em conflito com a moral social que se distancia do amor na sua verdadeira essência.

Por vezes, o narrador media as duas instâncias, pendendo ora para as evidências sociais e ora para o amor idealizado do casal, sem deixar de expor a vida íntima de Marcos e Lydia, com detalhes bastante eróticos, que devem chamar a atenção daquele mesmo leitor de jornal. Assim, a narrativa abarca deliberadamente uma outra esfera de sua relação com o jornalismo, de sorte que cadencia a representação da imprensa que se vinculava às estruturas econômicas e os voos da paixão pungente do casal, alinhando artificiosamente o que a própria narrativa concebe acerca do binômio realidade-ficção:

A vida é um grande romance de imaginação. Dentro desse romance, passam-se cenas e realizam-se fatos verdadeiramente espantosos, com todas as características sutilezas, artimanhas, ardilosidades, absurdos e lógicas que às vezes ultrapassam os próprios romances de ficção. A vida! Extraordinário romance de ficção encaixado na realidade! E quantos e quantos prodígios o pequeno romance da realidade não deve ao grande romance fantástico da imaginação!... Tantos, que dir-se-ia ser a vida um "folhetim" de prodígios inesperados, escrito pela imaginação fertilíssima do Destino e impresso, pelas mãos hábeis do gênio do absurdo, nos "rodapés" da realidade

Todos os romances têm um limite para a realização das suas urdiduras; o romance da vida não, conhece esse limite e alonga os seus prodígios, às vezes, até mesmo além do absurdo.

O caso sentimental de Marcos e Lydia entrara em pleno labirinto melodramático com visos bem esboçados de tragédia [...]. (idem: 93-94)

Assim, podemos ver as linhas de força em tensão por detrás do romance. O livro se divide em quadros da cidade e seus personagens, intercalados de tempos em tempos por sequências sobre o amor de Lydia e Marcos e a amizade de Bruno com este. As multidões das ruas, os cinemas e toda a atmosfera de uma cidade que brotava em temerosa erupção diante dos olhos das personagens são estruturantes. 0 enredo em torno do amor de Lydia e Marcos, assumidamente folhetinesco, ${ }^{11}$ atravessado pela insensatez do marido oportunista Oswaldo, é descolado para dar lugar à narração de casos das personagens secundárias sobre a vida noturna da cidade, basta ver a configuração de todo o capítulo quatro. Também neste ponto reside a tendência da narrativa-reportagem, tomada das impressões já publicadas como temas em Ronda da Meia Noite, inclusive com trechos inteiros transportados literalmente desta obra para o romance aqui em discussão. ${ }^{12}$ Assim, atado a uma literatura de viés realista-naturalista, com tom de denúncia, tendo a imprensa como um dos alvos, entrepõem-se o amor do casal e a "coragem de amar", sobretudo de Lydia, posto que sobre ela as convenções sociais aprofundadas pela família pesam com mais força. Brotam daí também as expectativas utópicas do militante (para quem não basta a descrição anatômica da sociedade, feita pela veia retratista do cronista-narrador) as quais incidem sobre a vida de Marcos e Lydia, narrada de fato como "folhetim" que 
se manifesta nos "rodapés da realidade". Do amor, que ao fim e ao cabo é viabilizado, brotaria uma "nova raça" redentora, subtítulo, aliás, da primeira edição do romance, ${ }^{13}$ corroborando com parte de preceitos estéticos revolucionários: ${ }^{14}$ "Para nosotros... el realismo debe tener un trasfondo más elevado; la descripción realista (debe) ser supeditada a un fin idealista" (Kropotkin apud Reszler).

Há, com efeito, em consonância uma arquitetura narrativa polivalente não só em favor do engajamento social e apropriação mercadológica simultaneamente, pensando na distribuição do texto, mas também dividida entre as tendências de um jornalismo literário francês, figurado em Marcos e Lydia, que aglutina, por seu turno, as estéticas fin de siècle e o folhetim, em um polo, e, em outro extremo, o jornalismo comercial, entrecruzado com a literatura, baseado na notícia, na informação investigativa de base estadunidense em fase de gestação. Ou seja, não só a verve jornalística, e blocos inteiros de texto, foi transplantada das reportagens para o romance, mas o foi também o próprio conflito entre as duas linhas de jornalismo em vigência, assimilado por Bulhões e Bertolli Filho como uma "Ronda por dois modelos de jornalismo" (2005: 57), fazendo referência à obra do escritor, identificáveis na trama e na conformação do romance.

A narrativa, enfim, é apresentada como uma obra direcionada em um primeiro momento para o leitor de jornal, maioria no período (Machado Neto 1973: 122). Os recursos do romance-folhetim, o desvendamento do funcionamento de setores da imprensa e da alta burguesia, cada vez mais conectados, bem como um passeio ao submundo da cidade, dialogam ou com o material habitualmente lido no jornal ou, de forma reflexiva, com seu mecanismo de funcionamento, percorrendo, dessa maneira, expressões diversas do mundo da imprensa, do entretenimento ao didatismo pela investigação testemunhal, com traços de reportagem crítica. $\mathrm{E}$ nessa mesma esteira, a obra é massivamente divulgada pela imprensa comercial, contribuindo com os próprios aparatos de propaganda do livro, como a improvável informação sobre sua tiragem de 20 mil exemplares, a dedicatória a "Todas as mulheres que acima das convenções, dos interesses, e além de todos os desastres, tiveram a coragem humana de amar", chamando a atenção das leitoras de romances e ao mesmo tempo engajando-as, por um lado; e, por outro, atraindo a leitura de homens à procura de satisfação às suas fantasias, tal como, na mesma direção, o aviso de que gravuras consideradas "algo realistas" foram extraídas do livro "em virtude de ordem superior", formando um coeficiente paratextual importante na tentativa de atração de leitores. A propaganda ganha, assim, ao menos duas acepções que se intercalam: uma comercial-apelativa e outra combativa-militante.

O setor editorial paulista, muito embora frágil, cresce no pós-guerra, gerando maior interesse pela leitura, em compasso com a popularização do noticiário bélico, que ganha repercussão nos jornais-empresas, como pelas obras nacionais, visto que o preço de livros importados cresce consideravelmente (Del Fiorentino 1982: 23). É possível compreender, por exemplo, a grande campanha que um jornal como $O$ Estado de S. Paulo faz em torno do livro na sua segunda edição em 1925, com intento de equipará-lo no mercado editorial a dois outros romances decisivos para época, especialmente em termos de vendagem, por tratar de temas tabus: La Garçonne, 1922, de 
Victor Margeritte e Mlle. Cinema, 1923, de Benjamin Costallat. ${ }^{15}$ No limite entre a reportagem do submundo, que aventava subjetividade, e o romance, continuando uma tradição iniciada por Eugène Sue e aclimatada por João do Rio, a obra é comparada às outras duas como forma de dar continuidade a uma literatura de apelo sexual, cuja curiosidade recai sobre a vida libidinosa da mulher, libertadora no caso do romance de Floreal, além de vibrar o eixo desse exercício literário, quase que exclusivamente produzido por escritores cariocas ou radicados no Rio de Janeiro, captando a paisagem urbana da cidade:

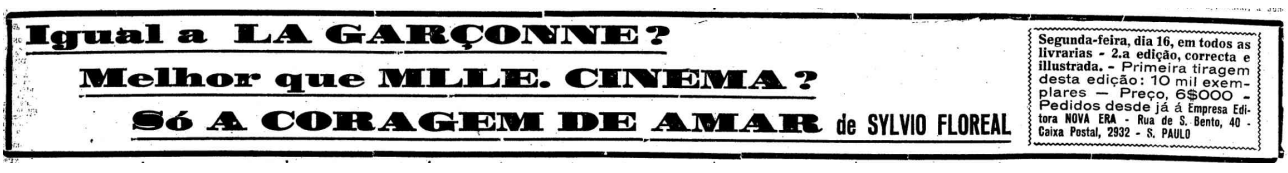

O Estado de S. Paulo - 13/3/1925.

Para Floreal, a recepção crítica de sua obra como sendo um romance de escândalo, que apesar da atmosfera dissidente era um tipo de literatura com alguma estabilidade, isto é, praticada com bases estéticas consagradas ou amplamente reconhecidas por um grande número de leitores, era desejada justamente pela sua capacidade de circulação e popularização. Brito Broca, por exemplo, fez o seguinte comentário sobre a obra, o qual podemos assumir como síntese de parte significativa da recepção da época: "aproveitando a vaga do neonaturalismo sensacionalista, publicava um romance de escândalo, A Coragem de Amar, em que sob o pretexto de mostrar as misérias sociais e causticá-las descrevia de maneira mais crua cenas eróticas e lascivas". Mais adiante, recorda o pedido do próprio Floreal para que ele, ainda crítico iniciante, ao comentar que lia A Coragem de Amar, escrevesse qualquer avaliação sobre o romance, demonstrando de forma ávida seu desejo estratégico de divulgação: "Pois então escreva umas coisas sobre ele. Escreva. Pode escrever o que quiser, criticá-lo à vontade, uma vez que não me faça insultos pessoais. Insulto pessoal não é crítica..." (Broca 1968: 178-179).

Assim como teria visitado João do Rio quando de sua passagem pela cidade de São Paulo, encontrou Benjamim Costallat, já consagrado por Mlle. Cinema, em março de 1924, depois da publicação da primeira edição do romance em análise, a fim de sondá-lo, esforçando-se para captar a atenção do escritor, estreitando contato e divulgando sua produção. ${ }^{16}$ Portanto, a comparação feita pela publicidade do jornal O Estado de S. Paulo (posteriormente a imprensa também passou a compará-lo a João do Rio com a publicação de suas reportagens) contava com certeza com sua chancela e desejo. Desse modo, o escritor mantinham-se no dilema, que só era possível pela dinamização ainda acanhada mas determinante do campo intelectual do período, centralizada pela prática jornalística, entre a "necessidade de criar segundo normas consagradas pela estética dominante" e a "opção por um posicionamento político, por parte do escritor, o que se reflete no conteúdo que clama por modificações sociais" (Zilberman 1984: 17). Se o jornalismo despontava como prática dominante de leitura, a sua incorporação pela literatura tendia a ganhar aceitação, ${ }^{17}$ tornando-se, logo, estética literária dominante, ainda que assumisse o risco, 
com efeito, da tendência ao consumo imediato, como no jornal.

Em vista disso, pode-se dizer que A Coragem de Amar não é uma literatura que almeja perdurar, postando-se menos como objeto contemplativo do que propositadamente imediato, sem grandes pretensões futuras, pois não só a venda da obra aparecia como fator iminente, mas também a mobilização social que dela urgia. A importância desse fato está justamente na concepção moderna do contexto, ou modernista do texto, rente ao cotidiano, ao presente. Uma concepção de literatura que tem consciência da sua durabilidade limitada, de suas subordinações, e que de certa forma almeja sua datação, dando-se pela aposta mercadológica e militante ao mesmo tempo, buscando a intensidade máxima extraída da atualidade dos fatos correntes, do que está na ordem do dia, expondo, nesse sentido, as possibilidades de atuação do campo literário do momento e suas determinações; uma literatura que se faz por dentro das convenções para assim implodi-las ou possibilitar que se evidencie o escritor através da divulgação de sua figura para um número de leitores que, embora residual se pensarmos demograficamente, em crescimento veloz, como nunca antes visto até então.

\section{NOTAS}

${ }^{1}$ Única obra do escritor a receber reedições póstumas por editoras de grande circulação: Boitempo em 2002, com prefácio e notas de Nelson Schapochnik e Paz e Terra em 2003, com prefácio e notas de Margareth Rago.

${ }^{2}$ Em nosso trabalho de mestrado, procuramos contextualizar com mais detalhes o lugar ocupado pelo escritor no interior do quadro intelectual do período, recorrendo, inclusive, a depoimentos de autores que estiveram com Floreal ao longo de sua vida literária. O trabalho também conta com uma antologia de textos do autor: https://teses.usp.br/teses/disponiveis/8/8149/ tde-15082018-132724/publico/2018_RafaelRodrigoFerreira_VCorr.pdf

${ }^{3}$ Ver Operários sem patrões: os trabalhadores da cidade de Santos no entreguerras, 2003, de Fernando Teixeira da Silva.

4Ver "As raízes libertárias no Brasil" contido na obra Os libertários, ideias e experiências anárquicas, 1988, de Edgard Rodrigues. ${ }^{5}$ Sylvio Floreal trabalhou como vendedor de assinaturas para a Revista do Brasil. Chegou a ter o cargo protegido por Monteiro Lobato em um momento de iminente demissão. Ver "O caso Sylvio Floreal" presente no livro Figuras de autor, figuras de editor: as práticas editoriais de Monteiro Lobato, da pesquisadora Cilza Carla Bignotto, 2018.

${ }^{6}$ Obra inconclusa do escritor.

${ }^{7}$ Sobre a influência do grupo Clarté no Brasil ver "O grupo Clarté no Brasil: da Revolução dos espíritos ao Ministério do Trabalho", inserido na obra Libertários no Brasil: memórias, lutas, cultura, de Michael M. Hall e Paulo Sérgio Pinheiro, publicado em 1986.

${ }^{8}$ Floreal teria publicado em data incerta um romance de nome Rei dos caça-dotes. Importante dizer que a figura movida pelo 
interesse estratégico em ascender a qualquer custo, ainda que pela apropriação do dinheiro alheio via matrimônio ou quaisquer outros tipos de golpe, fundamental para o entendimento da moral burguesa posta em revisão no romance, constitui uma espécie de personagem histórica, cada vez mais imponente no período republicano. $\mathrm{O}$ alpinismo social e suas estratégias aprimoravam-se em função das novas modalidades de relação social que a busca pelo capital impunha ferozmente, formando uma "democracia arrivista" (Sevcenko 1989: 56).

${ }^{9}$ O narrador resume a ligação intrínseca entre os ambientes mediados por Mancini, que "falava de finanças, política, jornalismo e mulheres, quase que a um tempo só" (Floreal 1925: 176).

10 "Os jornais falaram muito, segundo consta, do caso, e desde então, ela ficou conhecida por esse nome, que adotou como nome de guerra" (Floreal 1925: 52). Ademais, as conversas nas casas de prostituição são por vezes colocadas em primeiro plano, formando um verdadeiro documento das ilicitudes e imoralidades da cidade que se civilizava pela alta do café durante o dia e a baixa da conduta ética, que muitos dos membros da burguesia apregoavam, à noite. Do coronel ao homem de imprensa, todos davam lastro à sociabilidade noturna, que também funciona no romance como uma literatura que assume algum grau de apelo e sedução de um leitorado masculino.

${ }^{11}$ As produções advindas do romance-folhetim também foram de suma importância na imprensa operária paulista da época, constituindo-se como uma estratégia de atração e propaganda pela leitura com a intenção de despertar sensibilidade para as causas sociais libertárias (Leal 1999: 83-90).

${ }^{12} \mathrm{~A}$ fatura do texto e as imagens em torno da metrópole são muito similares entre ambos os livros (vale lembrar que já em 1922, Ronda da Meia-Noite estava no prelo, apesar de ter sido publicado somente depois do romance). Trechos da crônica-reportagem "A vertigem em marcha: fisionomia de um bairro" // são repetidos integralmente no romance, como seu parágrafo inicial: "O Brás, durante o dia, é um verdadeiro poema homérico de atividade e trabalho em marcha. É a ânsia em marcha, desabusada e audaciosa. É a luta em assomo febril de indômita avançada, penetrando, dominando todas as esferas da vida." Prontamente, seguido do parágrafo final da crônica, com pequenas alterações: "Visto cá do alto, é uma pincelada berrante de zarcão, onde as trompas insolentes das chaminés das suas fábricas expelem, numa ejaculação insistente para o alto, mascarando de negro a fisionomia do céu, atropelados rolos de fumaça! Tem o aspecto de anfiteatro em combustão, fervilhante, gerando em seu seio um monstro apocalíptico! Todo ele é progresso em fantástica escalada para o Futuro!" (Floreal 1925: 118-119.) A transposição direta da crônica para o romance pode sugerir que as publicações em jornal do escritor funcionavam com uma espécie de laboratório para produções mais extensas ou, ainda, que a fronteira entre os dois gêneros, jornalístico e literário, não estava demarcada com nitidez na época como tendemos a conceber na atualidade. Nesse sentido, tal compartilhamento revela-se de maneira cômoda e natural para o escritor, o que torna a atividade jornalística uma extensão do projeto literário e vice-versa. ${ }^{13}$ A primeira edição é de 1924, um ano antes da última edição em análise. Em toda obra de Floreal, e de outros escritores paulistas de mesma vertente, é bastante comum ver passagens inteiras de cunho eugenista, apregoando um discurso científico e determinista típico da época. Vale notar que tal perspectiva não era unânime, apesar de frequente, pois foi combatida por nomes importantes do momento como Lima Barreto, também simpático a causas anarquistas, o que faz relativizar a ideia de que todos pensavam assim e, portanto, justifica-se indevidamente a diluição da presença do conflito racial no debate intelectual e literário. No romance, isso se dá com bastante intensidade a partir da ideia de "nova raça" que surgiria de segmentos específicos da classe trabalhadora. Importa dizer também que mesmo para setores progressistas, como é o caso do anarquismo paulista presente no início do século XX, o sectarismo é visto por estudiosos da época no ideário da luta de classes dos imigrantes que "dificilmente se desligam de seus preconceitos étnicos", fator que pode, inclusive, explicar parte da falta de adesão de trabalhadores brasileiros, gerando "insucesso" na afirmação das ideias revolucionárias, segundo algumas revisões do período (Carelli: 66-67). 


\section{Cadernos de Literatura Comparada}

O jornalismo de Sylvio Floreal em A Coragem de Amar: texto, contexto e pretextos

${ }^{14} \mathrm{O}$ caso do contexto brasileiro é próprio pois difere de parte da concepção desenvolvida por André Reszler em La estética anarquista. Este sugere que a arte anarquista não se submeteria a qualquer prática capitalista para se estabelecer, ainda que direcionasse sempre sua arte crítica para o presente e revisitasse alguns caminhos do romantismo. Vemos que não só muitas das práticas literárias libertárias no Brasil se utilizam da "respectability das formas convencionais" para então tratar "do universo dos de baixo" (Hardman 1983: 118), mas que também se empenhavam muitas vezes, como Floreal, para "ocupar o código das classes dominantes e forçar a se abrir por dentro um novo modo de convivência cultural (Hardman/Prado 1985: 15). ${ }^{15} \mathrm{O}$ caso do contexto brasileiro é próprio pois difere de parte da concepção desenvolvida por André Reszler em La estética anarquista. Este sugere que a arte anarquista não se submeteria a qualquer prática capitalista para se estabelecer, ainda que direcionasse sempre sua arte crítica para o presente e revisitasse alguns caminhos do romantismo. Vemos que não só muitas das práticas literárias libertárias no Brasil se utilizam da "respectability das formas convencionais" para então tratar "do universo dos de baixo" (Hardman 1983: 118), mas que também se empenhavam muitas vezes, como Floreal, para "ocupar o código das classes dominantes e forçar a se abrir por dentro um novo modo de convivência cultural (Hardman/Prado 1985: 15). ${ }^{16}$ Matéria longa sobre a chegada do escritor carioca, na qual contém uma breve passagem sobre o contato entre Costallat e Sylvio Floreal foi publicada em 14 de março de 1924 no jornal paulista A Gazeta. Floreal teria oferecido a Costallat, após esperar sua saída do quarto de hotel em que se hospedava, "o exemplar com dedicatória de seu novo livro". Pela data, trata-se da primeira edição de A Coragem de Amar.

${ }^{17} \mathrm{O}$ reconhecimento dos projetos literários que flertavam com o jornalismo é tanto acadêmico, com a posse de João do Rio na Academia Brasileira de Letras em 1910, e editorial com o sucesso de vendas de Costallat no Rio de Janeiro (além do próprio João do Rio) e de Monteiro Lobato em São Paulo, que apadrinhou Floreal, especialmente após a extensa divulgação do texto jornalístico publicado em 1914 no Estado de São Paulo, A Velha Praga, transcrito em mais de sessenta jornais, passando a fazer parte do grupo de textos dispersos que compuseram o livro Urupês, publicado em 1918, que por sua vez vendeu cerca de 30 mil exemplares até 1925. Lobato, apesar de suas aproximações e distanciamentos acerca da tendência ao jornalismo na literatura, concebe a ideia de publicar em livro, após o sucesso de Urupês, textos que passaram antes pelo jornal como vemos no seguinte trecho de carta enviada ao amigo Godofredo Rangel, evidenciando o potencial mercadológico dessas produções: "O meu Urupês continua a sair bestialmente. Até enjoa. Tirei em fim de março mais quatro milheiros; pois só tenho em estoque uns quinhentos e estou premeditando a quinta edição. Vou dar agora Ideias de Jeca Tatu, coisas publicadas em jornal, sobretudo no Estado. Em seguida darei Cidades mortas, contos de Areias e Taubaté, dados no Minarete" (Lobato 2010: 442). 


\section{Bibliografia}

Bignotto, Cilza Carla (2018), Figuras de autor, figuras de editor: as práticas editoriais de Monteiro Lobato, São Paulo, Editora Unesp.

Broca, Brito (2004), A vida literária no Brasil - 1900, Rio de Janeiro, José Olympio/Academia Brasileira de Letras.

- (1968), Brito Broca Memórias, Rio de Janeiro, José Olympio.

Bertolli Filho, Cláudio/Bulhões, Marcelo Magalhães (2005), "Um jornalista da metrópole: a Paulicéia de Sylvio Floreal", in Comunicare, São Paulo, vol. 5, n. ${ }^{\circ} 2,2^{\circ}$ sem, 55-66.

Carelli, Mário (1985), Carcamanos e comendadores: os italianos de São Paulo: da realidade à ficção (1919-1930), Tradução de Lygia Maria Pondé Vassalo, São Paulo, Ática.

Couto, Ribeiro (1928), "O romance de Sylvio Floreal”, Illustração Brasileira, Rio de Janeiro.

Del Fiorentino, Teresinha Aparecida (1982), Prosa de ficção em São Paulo: produção e consumo (1900-1922), São Paulo, HUCITEC/Secretaria de Estado da Cultura.

Floreal, Sylvio (1925a), A Coragem de Amar, São Paulo, Nova Era.

- (1922), Attitudes. São Paulo, Casa Duprat.

- (1928), O Brasil Trágico. Impressões, visões e mistérios do Mato-Grosso, São Paulo, Rossetti.

-- (1925b), Ronda da Meia-Noite: Vícios, Misérias e Esplendores da Cidade de São Paulo, São Paulo, Typ. Cupolo.

-- (2002), Ronda da Meia-Noite: Vícios, Misérias e Esplendores da Cidade de São Paulo, São Paulo, Boitempo.

-- (2003), Ronda da Meia-Noite: Vícios, Misérias e Esplendores da Cidade de São Paulo, São Paulo, Terra e Paz.

Guimarães, Valéria (2013), Notícias diversas: suicídios por amor, leituras e cultura popular em São Paulo dos anos dez, Campinas, Mercado de Letras.

-- (2008), "Tensões e Ambuguidades na Crônica Sensacionalista: O Jornalismo no Rio de Janeiro e São Paulo no Início do Século XX", in Nas tramas da fição: história, literatura e leitura, São Paulo, Ateliê Editorial, 225-244.

Habermas, Jürgen (2014), Mudança estrutural da esfera pública: investigações sobre uma categoria da sociedade burguesa, São Paulo, Editora Unesp.

Hall, Michel M.; Pinheiro, Paulo Sérgio (1986), "O gurpo Clarté no Brasil: da Revolução dos espíritos ao Ministério do Trabalho", in Libertários no Brasil memória, lutas e cultura, São Paulo, Brasiliense.

Hardman, Francisco Foot (1983), Nem pátria nem patrão! Vida Operária e Cultura Anarquista no Brasil. São Paulo, Brasiliense.

--/Prado, Antonio Arnoni (1985), Contos Anarquistas: Antologia da Prosa Libertária no Brasil, São Paulo, Brasiliense.

Lobato, Monteiro (2010), A barca de Gleyre, São Paulo, Globo.

Leal, Claudia Feierabend (1999), Anarquismo em verso e prosa: literatura e propaganda na imprensa libertária em São Paulo (190o-1916), Dissertação (mestrado em Teoria e História 
Literária) Instituto de Estudos da Linguagem - Universidade Estadual de Campinas (Instituto de Estudos da Linguagem), Campinas.

Machado Neto, Antônio Luís (1973), Estrutura social da república das letras: sociologia da vida intelectual brasileira, 1870-1930, São Paulo, EDUSP.

Medina, Cremilda (1988), Notícia, um produto à venda: jornalismo na sociedade urbana industrial, São Paulo, Summus.

Rago, Margareth (2003), "Apresentação: Nas margens da Paulicéia", in Ronda da Meia-Noite:

Vícios, Misérias e Esplendores da Cidade de São Paulo, São Paulo, Paz e Terra, 3-7.

Rama, Ángel (2015), A cidade das letras, São Paulo, Boitempo.

Rodrigues, Edgar (1988), "As raízes libertárias no Brasil”, in Os libertários: ideias e experiências anárquicas, Petrópolis, Vozes.

Sarti, Ingrid (1981), Porto Vermelho - Os Estivadores Santistas no Sindicato e na Política. São Paulo, Paz e Terra.

Schapochnik, Nelson (2002), "Apresentação: Prelúdio à Sinfonia Cosmopolita", in Ronda da Meia-Noite: Vícios, Misérias e Esplendores da Cidade de São Paulo, São Paulo, Boitempo, 1317.

Silva, Fernando Teixeira (2003), Operários sem patrões: os trabalhadores da cidade de Santos no entreguerras, Campinas, Editora da UNICAMP.

Sevcenko, Nicolau (1983), Literatura como missão: tensões sociais e criação cultural na Primeira República, São Paulo, Brasiliense.

Zilberman, Regina (1984), "A Literatura e o Apelo das Massas", in Literatura em tempo de cultura de massa. São Paulo, Nobel. 